\title{
MICA Polymorphism, Association with Diseases and the Role of Anti-MICA Antibodies in Organ and Stem Cell Transplantation
}

\author{
Meri Kirijas*, Mirko Spiroski \\ Institute of Immunobiology and Human Genetics, Faculty of Medicine, Ss Cyril and Methodius University of Skopje, Republic \\ of Macedonia
}

\begin{abstract}
Citation: Kirijas M, Spiroski M. MICA Polymorphism, Association with Diseases and the Role of Anti-MICA Antibodies in Organ and Stem Cell Transplantation. Maced J Key words: Major histocompatibility complex class chain-related genes (MIC); MICA polymorphism; association with diseases; anti-MICA antibodies; organ and stem cell transplantation.

"Correspondence: Meri Kirijas, MD, PhD candidate. Institute of Immunobiology and Human Genetics, Faculty of Medicine, Ss Cyril and Methodius University of Skopje, 50. Divizija No 16, PO Box 60 1109 Skopje, Republic of Macedonia. E-mail: merikirijas@gmail.com

Received: 12-Mar-2013; Revised: 27-May-2013; Accepted: 20-Jun-2013; Online first: 20-Jul-2013 Copyright: () 2013 Kirijas M. This is an openaccess article distributed under the terms of the Creative Commons Attribution License, which permits unrestricted use, distribution, and reproduction in any medium, provided the original author and source are credited.

Competing Interests: The authors have declared that no competing interests exist.
\end{abstract}

\begin{abstract}
Major histocompatibility complex class 1 chain-related genes $(M I C)$ are part of the non-classical MHC genes located on the short arm of chromosome 6. MICA comprises of approximately 11 kb DNA and encodes polypeptide of 383 amino acids. The expression of MICA is limited to the surface of the epithelial cells, fibroblasts, keratinocytes and monocytes, but not on the surface of CD4+, CD8+ and CD19+ lymphocytes. It manifests its role by binding with the NK cell receptor NKG2D. There are 84 different alleles for MICA due to discovered polymorphisms in the exons 2 to 5 . The aim of this review is to present the data known so far about the association of MICA with different diseases and the role of anti-MICA antibodies in organ and stem cell transplantation. The frequency of different MICA alleles and their association with different HLA$B$ alleles, as well as the association of MICA with different inflammatory diseases, infection diseases and tumors was determined. Post- and pre-transplant anti-MICA antibodies are associated with antibody-mediated rejection in kidney and heart transplantation. Patients with hematopoietic stem cell transplantation, which have MICA mismatch, have higher frequency of graft versus host disease episodes. In spite of lack of conclusive data about the role of antiMICA antibodies in organ and stem cell transplantation, there is still clinical relevance for investigation of the polymorphisms of the MICA gene and anti-MICA antibodies.
\end{abstract}

\section{Introduction}

Bahram et al.,1994 [1] described new group of non-classical $M H C$ genes, which are highly divergent of all known MHC class 1 chains, called MHC class I chain-related genes (MIC). They probably separated early in the evolution from mammalian class 1 genes. Actually, in the search of the HLA-B region for other expressed genes, the MICA gene was identified. In the same time, another group of researchers found a group of nonclassicalMHC genes that they named PERB11, but it was soon realized that PERB11.1 is actually MICA, and PERB11.2 is MICB [2]. In the 2-kb MHC class 1 region of chromosome $6,6 \mathrm{MIC}$ loci were identified (The MHC Sequencing Consortium 1999) and in 2004 was updated to 7 MIC loci [3, 4]. MICA gene comprises of approximately $11 \mathrm{~kb}$ DNA and is located around $46 \mathrm{~kb}$ centromeric from $H L A-B$, whereas $M I C B$ is $89 \mathrm{~kb}$ further centromeric from MICA (MICC, MICD, MICE, MICF and MICG are pseudogenes).

The organization of the exon-intron structure of the MICA gene is distinct from all known class 1 genes. These MICA characteristics are: the unique transmembrane and cytoplasmic tail sequences, 3 extra cystein residues in the $\alpha 1$ and $\alpha 3$ domains and several potential $\mathrm{N}$-linked glycolysation sites. The MICA gene has 6 exons, which encode leader peptide, three extracellular domains ( $\alpha 1, \alpha 2$ and $\alpha 3$ ), transmembrane segment and carboxy-terminal cytoplasmic tail [1]. MICA is highly polymorphic in all three alpha domains and has $15-36 \%$ sequence homology with the classical class 1 genes, and total $83 \%$ homology with MICB [5]. Unlike MHC class 1 , MICA doesn't associate with beta-2 microglobulin [6]. 


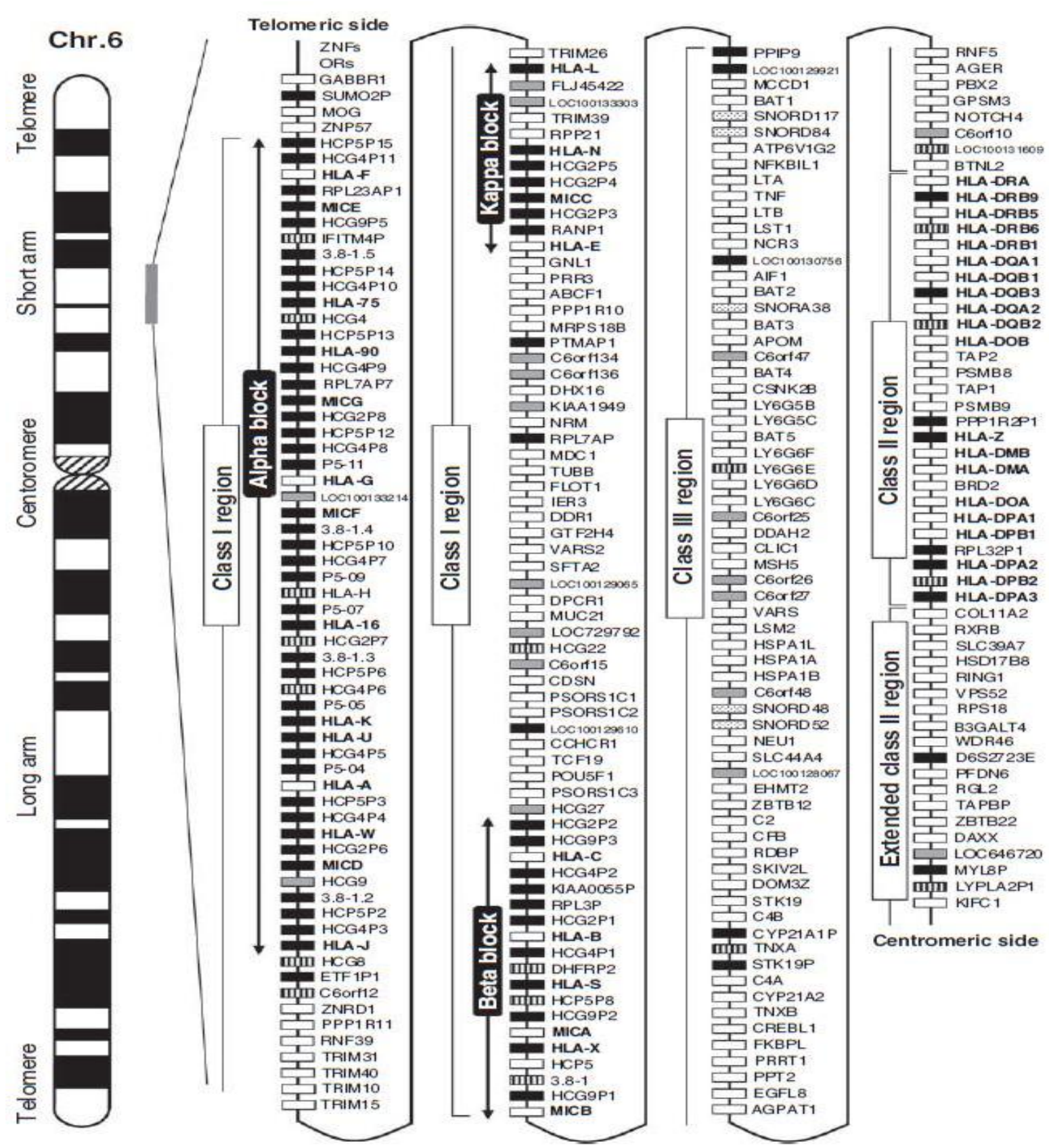

Figure 1: Gene map of the human leukocyte antigen (HLA) region. The major histocompatibility complex (MHC) gene map corresponds to the genomic coordinates of 29677984 (GABBR1) to 33485635 (KIFC1) in the human genome build 36.3 of the National Center for Biotechnology Information (NCBI) map viewer. The regions separated by arrows show the HLA subregions such as extended class I, classical class I, class III, classical class II and extended class II regions from telomere (left and top side) to centromere (right and bottom side). White, gray, striped and black boxes show expressed genes, gene candidates, non-coding genes and pseudogenes, respectively. The location of the alpha, beta and kappa blocks containing the cluster of duplicated HLA class I genes in the class I region are indicated [4].

MICA encodes a polypeptide of 383 amino acids, which has $\mathrm{Mr}$ of approximately $42-44 \mathrm{kDa}$, but the mature protein has a $\mathrm{Mr}$ of $\sim 65 \mathrm{kDa}$. This difference is due to glycolisation at 8 potential $\mathrm{N}$-glycosilation sites located along the 3 extracellular domains [6]. MICA encodes synthesis of a stress-induced protein which has limited pool of expression in the human tissues. It is thought that MICA plays a role in the humoral immunity through his interaction with NK cells receptor NKG2D, increasing NK cell response. They also interact with the $y \delta T$ cells and CD8+ $\alpha \beta T$ cells [7].
MICA antigens are mostly found on the surface of the epithelial cells and fibroblasts [1], keratinocytes and monocytes, but not on the surface of CD4+, CD8+ and CD19+ lymphocytes [8]. PHA-activated CD4+ and CD8+ $T$ cell blasts express MICA [9]. MICA are also present on the surface of the gastrointestinal tract [6], so GIT symptoms in GVHD are thought to be consequence of MICA antigen mismatch in donors and recipients of stem cells. However, a systemic transcriptional analysis of MIC genes with Northern blotting showed that both MICA and MICB are widely 
transcribed in virtually every examined organ, with the exception of the central nervous system [10]. MICA antigens can be found on the surface of some melanomas and $T$ cell leukemia's [11], which suggests that their expression can be related to the process of neotransformation. No difference was observed in the MIC transcription in healthy vs. tumours tissues in some types of solid organ tumors (colon, rectum, breast, uterus, kidney, lung, bladder, esophagus, liver, stomach) [10].

\section{Polymorphisms of MICA and allele frequency}

With the help of PCR-SSP, SSOP and SBT techniques, numerous MICA and MICB alleles have been identified. According to HLA nomenclature (http://hla.alleles.org/nomenclature/stats.html) there are 84 alleles and 71 protein for MICA and 40 alleles and 26 proteins for MICB published so far. The MICA gene polymorphisms are located along exons 2 to 5 . Polymorphisms in exons 2 to 4 are nucleotide substitutions, which encode amino acid substitutions in the alpha1, alpha2 and alpha3 domains; whereas polymorphisms in exon 5 consist of different number of GCT repeats that encode for 4 to 10 Ala residues in the transmembrane domain (designated A4, A5, A5.1, A6 and A9) [12]. MICA extracellular alleles show certain association patterns with the transmembrane STR which are shown on Table 1 [13]. A change of the amino acid methionine (Met) to valin (Val) at position 129 of the alpha2-heavy chain domain classifies the MICA proteins into strong and weak binders of the NKG2D receptor, which in turn influences effector cell function [6].

Table 1: Association of MICA extracellular allele with TM-STR [13].

\begin{tabular}{ll}
\hline MICA extracellular allele & TM-STR \\
\hline$M I C A^{*} 001$ & $A 4$ \\
$M I C{ }^{*} 002$ & $A 9$ \\
$M I C A^{*} 004$ & $A 6$ \\
$M I C A^{*} 007$ & $A 4$ \\
$M I C A^{*} 008$ & $A 5.1$ \\
$M I C A^{*} 009$ & $A 6$ \\
$M I C{ }^{*} 010$ & $A 5$ \\
$M I C A^{*} 011$ & $A 6$ \\
$M I C A^{*} 012$ & $A 4$ \\
$M I C A^{*} 016$ & $A 5$ \\
$M I C A^{*} 018$ & $A 4$ \\
$M I C A^{*} 019$ & $A 5$ \\
\hline
\end{tabular}

Most frequent MICA allele in North American Caucasoid [14] and in Western Europe [15] is MICA*008 (5A5.1) which has shorter transmembrane domain and no cytoplasmic tail due to premature stop codon in exon 5. Despite that, it is efficiently expressed at the cell surface [6] where it can engage NKG2D. On Table 2 are shown the three most frequent MICA alleles in different regions according to the data on www.allelefrequencies.net. More detailed information about the frequency of different MICA alleles is available on the website.

Table 2: The most frequent MICA alleles in different regions (data from www.allelefrequencies.net).

\begin{tabular}{clccc}
\hline Region & MICA Allele & $\begin{array}{c}\text { Allele } \\
\text { frequency }\end{array}$ & $\begin{array}{c}\text { Sample } \\
\text { size }\end{array}$ & Reference \\
\hline Asia & $A 5$ & 0.390 & 200 & {$[77]$} \\
& $M I C A^{*} 010$ & 0.390 & 41 & {$[78]$} \\
& $M I C A^{*} 008$ & 0.350 & 66 & {$[78]$} \\
\hline Eastern & $A 5.1$ & 0.443 & 108 & {$[79]$} \\
Europe & $A 6$ & 0.407 & 27 & {$[80]$} \\
& $A 9$ & 0.232 & 108 & {$[79]$} \\
\hline Middle & $A 6$ & 0.500 & 18 & {$[80]$} \\
East & $A 5.1$ & 0.222 & 18 & {$[80]$} \\
& $A 5$ & 0.167 & 18 & {$[80]$} \\
\hline North & $M I C A^{*} 008: 01$ & 0.268 & 82 & {$[81]$} \\
Africa & $M I C A^{*} 004$ & 0.232 & 82 & {$[81]$} \\
& $M I C A^{*} 009: 02$ & 0.140 & 82 & {$[81]$} \\
\hline North & $M I C A^{*} 008$ & 0.550 & 242 & {$[82]$} \\
America & $M I C A^{*} 002: 01$ & 0.300 & 60 & {$[83]$} \\
& $M I C A^{*} 004$ & 0.295 & 39 & {$[83]$} \\
\hline South \& & $M I C A^{*} 002: 01$ & 0.641 & 174 & {$[84]$} \\
Central & $M I C A^{*} 027$ & 0.352 & 60 & {$[85]$} \\
America & $M I C A^{*} 010$ & 0.341 & 89 & {$[84]$} \\
\hline Sub- & $M I C A^{*} 002: 01$ & 0.424 & 46 & {$[83]$} \\
Saharan & $M I C A^{*} 008: 01$ & 0.328 & 32 & {$[83]$} \\
Africa & $M I C A^{*} 004$ & 0.270 & 74 & {$[83]$} \\
\hline Western & $M I C A^{*} 008: 01$ & 0.530 & 166 & {$[15]$} \\
Europe & $A 5.1$ & 0.370 & 154 & {$[86]$} \\
& $A 6$ & 0.370 & 158 & {$[27]$} \\
\hline
\end{tabular}

Because of the closeness with $H L A-B$, it was found that MICA and HLA-B loci are in linkage disequilibrium. There are a lot of studies that show the association of different MICA and HLA-B alleles. The most frequent $(>10 \%)$ are summarized on Table 3. More details are available on www.allelefrequencies.net. One MICA allele can be associated with different $H L A-B$ alleles and vice versa [14].

Table 3: Frequency of MICA-HLA association from different studies (data from www.allelefrequencies.net)

\begin{tabular}{|c|c|c|c|}
\hline Haplotype & Frequency (\%) & Sample size & Reference \\
\hline $\mathrm{MICA}^{*} 008-\mathrm{B}^{*} 08: 01$ & 20.6 & 242 & [82] \\
\hline $\mathrm{MICA}^{*} 027-\mathrm{B}^{*} 40: 02$ & 20.4 & 42 & [85] \\
\hline 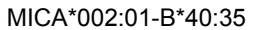 & 20.0 & 42 & [85] \\
\hline $\mathrm{MICA}^{*} 004-\mathrm{B}^{*} 42: 01$ & 18.0 & 39 & [83] \\
\hline $\mathrm{MICA}^{*} 002: 01-\mathrm{B}^{*} 53: 01$ & 16.7 & 39 & [83] \\
\hline $\mathrm{MICA}^{*} 002: 01-\mathrm{B}^{*} 53: 01$ & 15.2 & 46 & [83] \\
\hline $\mathrm{MICA}^{*} 010-\mathrm{B}^{*} 46: 01$ & 14.7 & 255 & [87] \\
\hline $\mathrm{MICA}^{*} 008: 01-\mathrm{B}^{*} 15: 03$ & 14.1 & 32 & [83] \\
\hline $\mathrm{MICA}^{*} 019-\mathrm{B}^{*} 15$ & 13.1 & 255 & [87] \\
\hline $\mathrm{MICA}^{*} 002: 01-\mathrm{B}^{*} 53: 01$ & 12.8 & 74 & [83] \\
\hline $\mathrm{MICA}^{*} 002-\mathrm{B}^{*} 53$ & 12.4 & 201 & [88] \\
\hline $\mathrm{MICA}^{*} 004-\mathrm{B}^{*} 44$ & 12.1 & 165 & [89] \\
\hline $\mathrm{MICA}^{*} 008-\mathrm{B}^{*} 07: 02$ & 12.0 & 242 & [82] \\
\hline MICA*002:01-B*53:01 & 11.7 & 60 & [83] \\
\hline MICA*004-B*44 & 11.5 & 199 & [90] \\
\hline MICA*008:01-B*40:01 & 11.5 & 100 & [91] \\
\hline $\mathrm{MICA}^{*} 004-\mathrm{B}^{*} 49: 01$ & 10.9 & 32 & [83] \\
\hline $\mathrm{MICA}^{*} 004-\mathrm{B}^{*} 44: 03: 01$ & 10.6 & 82 & [81] \\
\hline $\mathrm{MICA}^{*} 008-\mathrm{B}^{*} 07$ & 10.6 & 165 & [89] \\
\hline $\mathrm{MICA}^{*} 008-\mathrm{B}^{*} 44: 02$ & 10.6 & 242 & [82] \\
\hline $\mathrm{MICA}^{*} 010-\mathrm{B}^{*} 15: 01$ & 10.4 & 139 & [92] \\
\hline $\mathrm{MICA}^{*} 010-\mathrm{B}^{*} 40$ & 10.3 & 199 & [90] \\
\hline $\mathrm{MICA}^{*} 002-\mathrm{B}^{\star} 38$ & 10.0 & 95 & [89] \\
\hline $\mathrm{MICA}^{*} 008-\mathrm{B}^{*} 08$ & 10.0 & 103 & [93] \\
\hline $\mathrm{MICA}^{*} 027-\mathrm{B}^{*} 40$ & 10.0 & 199 & [90] \\
\hline
\end{tabular}




\section{MICA and inflammatory diseases}

The proximity of the HLA locus, its polymorphism and the interaction with the NKG2D receptor, make the MICA gene target for many association studies. The polymorphism of MICA exon 5 microsatellite (TM) was determined in a group of 226 patients with different clinical forms of psoriatic arthritis in a Italian study [16]. They found significant positive association between MICA-A9 and the peripheral symmetric polyarthritis form combined with spondilitis and negative association of the MICA-A5, A4 genotype with psoriatic arthritis. Another group studied the frequency of extracellular polymorphisms of the MICA alleles in 128 Tai psoriasis patients [17]. $M I C A^{*} 010$ and $M I C A^{*} 017$ were associated with Type 1 psoriasis and $M I C A^{\star} 010$ with Type 2 . The haplotype analysis showed that MICA*008-HLA-B*13-Cw*0602 and $\mathrm{MICA}^{*} 010-\mathrm{HLA}-\mathrm{B}^{*} 4601-\mathrm{Cw}^{*} 01$ were significantly increased in both Type 1 and Type 2, while $\mathrm{MICA}^{*} 002-\mathrm{HLA}-\mathrm{B}^{*} 38-\mathrm{Cw}^{*} 07(01-03)$ and $\mathrm{MICA}^{*} 017-$ HLA-B*57-Cw*0602 were elevated only in Type 1. Most of the associations of MICA with psoriasis and psoriatic arthritis are dependent on linkage disequilibrium with $H L A-B$ and $H L A-C$ risk alleles. Independently of HLA, MICA*016 influences the risk of developing psoriasis without arthritis, while homozygocity for MICA*00801 increases the risk of developing psoriatic arthritis in patients with psoriasis [18].

Stress-inducible MICA is aberrantly expressed in rheumatoid arthritis synoviocytes and stimulate autologous CD4+CD28- $T$ cell cytokine and proliferative responses [19]. This was the reason why MICA polymorphisms were analyzed in patients with rheumatoid arthritis. The non-synonymously coding SNP MICA-250 (rs1051794, Lys196Glu) was associated $(P=0.014)$ with rheumatoid arthritis in a study of 300 French Caucasian individuals (negative for HLA-DRB1 risk alleles) belonging to $100 \mathrm{RA}$ trio families [20].

The association of $H L A-B 27$ with ankylosing spondilitis is well documented. Su $\mathrm{H}$. et al. [21] found that $M I C A^{*} 007$ was more frequent in patients with ankylosing spondilitis than controls with dominance of the haplotype MICA*007-B27. It's suggested that the higher frequency of MICA is due to its strong linkage disequilibrium with HLA-B27, and MICA alone is not associated with ankylosing spondilitis [22].

Goto et al. analyzed the association of MICA A4 allele and acute anterior uveitis. MICA A4 (microsatellite allele with four repetitions of GCT/AGC) was present with statistically higher frequency in the group of patients with HLA-B27 positive acute anterior uveitis and was in linkage disequilibrium with HLAB27 [23].

$H L A-B^{*} 51$ is known to be associated with Behcet's disease and Hughes $\mathrm{EH}$ et al. [24] analyzed the association of MICA with the disease. MICA*009 was more frequent in the group of patients with
Behcet's disease and was in linkage disequilibrium with $H L A-B^{*} 51$. Same results were obtained from Munoz-Saa I. et al. [25]. MICA might influence the pathogenesis of Behcet's disease through its interaction with NK and gammadelta T cells.

Systemic lupus erythematosus (SLE) is a disease with unknown etiology, but with predisposing genetic background. DRB1*03-DQA1*0501DQB ${ }^{*}$ 0201-B8 haplotype has the strongest genetic association identified so far with SLE (26). Gambelunghe et al. [27] found that MICA5/5.1 genotype was positively associated (OR=28.9, corrected $\mathrm{P}<0.0015)$ and MICA9 was negatively associated with SLE $(O R=0.2$, corrected $P<0.0005)$. DR3-DQ2-MICA5.1 and DR3-DQ2-MICA5 haplotypes was more frequent in patients with SLE $(P<0.011)$. However, in a Japanese study [28], MICA ${ }^{129}$ Met;A9 haplotype was positively associated with SLE patients who were negative for $H L A-D R B 1 * 15: 01$, whereas simultaneous presence of MICA ${ }^{129}$ Met;A9 and HLA$D R B 1 * 15: 01$ showed highest likelihood of association (OR 2.4) in the patients.

Celiac disease is an autoimmune disease that affects the small intestine in genetically predisposed people. There is strong MICA expression on the surface of the cells in the gut in patients with active celiac disease [29]. This effect is mediated by IL-15 and triggers direct activation and costimulation of intraepithelial T lymphocytes, which can damage the enterocytes through NKG2D/MICA interaction after gliadin-induced expression of MICA on gut epithelium [29]. Positive association for MICA allele A4 and negative for $A 9$ was determined in Basque families with celiac disease. The haplotype A5.1-DRB1*0301 was associated with risk of disease, but the stratification analysis didn't show independent contribution of MICA alleles to risk of celiac disease [30]. In another Spanish study, positive association of MICA A5.1 with celiac disease, independently of CDpredisposing DQ2 haplotype, was found (31). MICA9 has protective role in autoimmunity [32].

Few studies analyzed the association of different MICA polymorphisms and type 1 diabetes mellitus, autoimmune disease that results from destruction of the insulin-producing beta cells. There is statistically significant positive association of MICA $A 5$ and $A 5.1$ and type 1 diabetes mellitus [33-37] and negative for MICA9 [36] and A6 [35]. OR of 54 was obtained for the haplotype DRB1*04-DQA1*0301DQB1*0302-MICA5 [33].

Another autoimmune disease associated with MICA is alopecia areata (AA), organ specific autoimmune disease caused by T-cell infiltrates surrounding hair follicles. The patchy AA was significantly associated with $M I C A^{*} 5.1$, whereas $M I C A^{*} 6$ was associated with all types of $A A$. They are part of extended haplotypes associated with AA HLADQ1-DR6-MICA ${ }^{*} 5.1$ and HLA-DQB1*0201-DR3$M I C A * 5.1$ [38]. 


\section{MICA and tumors}

There are many studies that confirm the MICA expression in different types of tumors, like of the lung, breast, kidney, liver, ovary, prostate, colon, melanomas and some types of leukemias [12]. The exact role of MICA in tumor transformation is not yet defined, but it regulates the immune response through binding with the NKG2D receptor on the NK cells and mediates the lysis of epithelial and non-epithelial tumors. Hepatocellular carcinoma is a lung cancer who develops, in most of the cases, after chronic hepatitis B and C infection. Single nucleotide polymorphism (SNP) rs2596542 located in the MICA promoter region is significantly associated with the risk of HCV- and HBV-induced hepatocellular carcinoma [39]. The patients with hepatocellular carcinoma have higher serum level of soluble MICA $[39,40]$ and high value for sMICA is associated with poorer prognosis of HCC. MICA-A5.1 allele is associated with $\mathrm{HCC}(\mathrm{P}=0.036)$ in a South China Han population [41].

Luo et al. [42] analyzed the role of different MICA polymorphisms in leukemia. They found positive association for MICA A5 $(\mathrm{P}<0.0005)$ and negative association for MICA A5.1 and MICA*008 $(\mathrm{P}=0.0235$ and $\mathrm{P}=0.0329$, respectively) with leukemia. Increased risk for leukemia was found for MICA A5 and MICA*010 homozygotes, whereas heterozygotes for MICA*008 and MICA A5.1 were linked with decreased risk for leukemia.

MICA expression is undetectable in normal skin, primary nevi (intradermic, junction, mixed, lentigo and congenital samples), benign lesions (seborrheic keratosis), premalignant lesions (actinic keratosis) and benign basocellular cancer, whereas in melanoma there is high expression of MICA. Thus, analysis of MICA expression in different skin samples can help differentiate between benign and malignant nevi [43].

\section{MICA and infection}

The up-regulation of MICA expression on the surface of dendritic and epithelial cells after microbial infection, like with Mycobacterium tuberculosis [44], led to investigation of the polymorphisms of MICA alleles in patients with tuberculosis. Significant negative association for $H L A-A^{*} 02$ and $H L A-B^{\star} 18$ and for the haplotype HLA-B* $18-\mathrm{MICA}^{*} 018$ was found in a Brazilian study, which suggests protective role for $H L A-A^{*} 02$ and $H L A-B^{*} 18$ (in a linkage disequilibrium with $M I C A^{*} 018$ ) [45]. Negative association, and protective role, was also found in patients with leprosy for the MICA*027, and MICA*010 and MICA*027 were negatively associated with multibacillary leprosy [46]. In a study of $230 \mathrm{sib}$ pairs with paucibacillary leprosy in South India, MICA*5A5.1 was associated with susceptibility to leprosy [47]. MICA*5A5.1 allele has a single $G$ insertion occurring in a background of five alanine repeats, causes frameshift mutation which results in a premature stop codon and a truncated transmembrane domain. It's importance is still unknown.

Up-regulation of MICA expression was found also in viral infections, i.e. CMV infection induces upregulation of the MICA expression in vitro on cultured fibroblasts and endothelial cells and in vivo in interstitial pneumonia [48]. However, another study showed down-regulation of full-length MICA expression after CMV infection in a U373 astrocytoma cell line and not for the truncated form [49]. Fibroblasts with decreased MICA were protected from NK cell killing, whereas the virus-infected cells with truncated form of MICA were destroyed. Moenkemeyer et al. [50] found positive association of MICA5.1 with CMV reactivation in HIV-1-infected patients $(p=0.032)$.

Dendritic cells from Hepatitis $C$ virus-infected patients couldn't up-regulate MICA expression after IFN-alpha stimulation and failed to activate NK cells $[51,52]$. This effect contributed to prolonged HCV infection due to poor dendritic cell-NK cell cross-talk and lower NK cell activation [12]. MICA*015 was associated with recovery from $\mathrm{HCV}$ infection and chronic hepatitis B infection [53], but because it was detected in a small fraction of persons, additional studies are necessary.

\section{Anti-MICA antibodies}

After the discovery of MICA antigens on the surface of endothelial cells and their polymorphism, the question about the ability of the human organism to create anti-MICA antibodies was raised. Zwirner and his colleagues created three recombinant MICA proteins, which consisted of the alpha 1 , alpha 2 and alpha 3 domains and with the help of enzyme-linked immunosorbent assay tried to analyze if MICA can be target for specific antibodies in the sera of transplanted patients [54]. In the sera samples collected in different periods after organ transplantation, the presence of specific anti-MICA antibodies was detected. Although with this finding was raised the question of how this persons were immunized, the fact that these polymorphic, HLAsimilar MICA molecules, expressed on the surface of endothelial cells, were recognized by specific antibodies in the sera from transplanted patients suggests that MICA can be target molecule in allograft rejection.

\section{Methods of antibody identification}

With the aim to discover if people can create anti-MICA antibodies and their meaning, Zou Y. and his colleagues developed a method for detection with the use of Luminex beads. They created recombinant MICA antigens in insect cells comprised of signal peptide, extracellular domains of $\mathrm{MICA}^{*} 001$, 
MICA*002, MICA*004, MICA*008 and MICA*009, sixhis tag sequence and a biotinylation peptide. These proteins were expressed on HighFive insect cells, they were purified with nickel affinity agarose and were attached to Luminex beads [55]. In the next period, a few modifications were done to make the detection of these antibodies more specific. This modifications included use of Sf9 insect cells instead of HighFive, the conjugation of the MICA proteins with carboxilated Luminex beads was done with carbodiimide hydrochloride and two steps of purification were used, first based on his-tag with nickel agarose, and the second included immunoabsorption with anti-MICA monoclonal antibody 6B3, attached to sepharose beads [56]. In order to determine which polymorphisms can be identified with anti-MICA antibodies, Zou Y. and colleagues created soluble MICA recombinant proteins, which represent 11 common alleles, two hybrid alleles and two single amino acid mutated alleles. The procedure included first determination of the pattern of a serum on MICAconjugated Luminex beads, than absorption of the serum with transfected cells, which express only one defined MICA allele, and at the end eluation of the antibodies with acid. With this experiment, they identified 14 patterns of reactivity: antibodies that recognize single alleles, small groups consisting of 2 , 3 or 4 alleles and larger groups called MICA-G1 and MICA-G2 [56]. The identification of target epitopes for antibody binding helps in the understanding of the development of MICA antibodies, which are mainly, result of donor-specific allo-immunization. Similar results were obtained from Dequesnoy and colleagues. They tested 6 sera from patients, who had been sensitized after transplantation, with Luminex panels of single MICA alleles and the HLAMatchmaker program to analyze serum antibodies pattern. The HLAMatchmaker analysis revealed generally consistent antibody reactivity patterns, which correlate with the presence of specific eplets [57].

\section{Mechanisms of MICA antibodies-induced allograft injury}

Complement-mediated and antibodydependent cell-mediated cytotoxicity are the mechanisms by which donor-specific anti-HLA alloantibodies initiate renal allograft rejection [58]. Apparently, MICA can't fix complement because C4d positivity is rare in anti-MICA antibodies positive patients [59]. However, Zou Y. and colleagues in order to determine whether MICA is a target for complement-dependent cytotoxicity, produced monoclonal antibodies by immunization of mice with recombinant $\mathrm{MICA}^{*} 008$ and also investigated human alloantibodies and observed the patterns of reactivity with ELISA, Western blot and flow cytometry. Their results suggested that MICA alloantigens may be more immunogenic than previously suspected and that they may contribute to the pathogenesis of antibody-mediated response (AMR) through complement-mediated injury [60]. Furthermore, Alvarez-Marques $\mathrm{A}$. and colleagues investigated two groups of patients with AMR, one with C4d deposition in renal biopsies and the second patients with graft dysfunction negative for C4d. Anti-MICA donorspecific antibodies were more frequent in the $\mathrm{C} 4 \mathrm{~d}+$ group $(21 \%)$ than in the C4d- group $(7.7 \%, p=0.15)$. Although the investigated groups were not large, the detection of DSA anti-MICA antibodies suggested their role in the antibody-mediated allograft immune response after kidney transplantation [61].

\section{The role of anti-MICA antibodies in kidney transplantation}

Anti-HLA antibodies formed before the kidney transplantation can produce immediate reaction, whereas the antibodies formed post-transplantation are not associated with immediate reaction, but rather initiate process of damage and repair in the endothelium, resulting in the characteristic construction of the blood vessels, commonly found in chronic rejection. In order to determine the role of post-transplant anti-HLA and anti-MICA antibodies in chronic allograft rejection after kidney transplantation, Mizutani et al. [62] tested 679 postoperative serial serum samples from 39 patients who rejected their grafts and 26 with functioning grafts. Patients who rejected transplants more frequently had anti-HLA and anti-MICA antibodies compared to patients without rejection (95\% vs. 58\%, p<0.01). The peak PRA, determined with Luminex, was $19.6 \%$ in rejected transplants and $6.7 \%$ in functioning transplants $(p<0.05)$. Not all of these antibodies were donorspecific and some of them appeared and then were lost before graft rejection occurred. Mizutani et al. think that donor-specific antibodies are often absorbed in the organ and fixed onto the antigenic sites of the donor kidney vasculature. But when they saturate the endothelium, they spill out into the circulation. Martin et al., who showed that donor-specific antibodies, which couldn't be found before the nephrectomy, were noted after removal of the graft [63], confirmed this. Similar results were obtained from Ozawa et al. [64], $93 \%$ of 266 kidney recipients with graft failure had anti-HLA antibodies and $21 \%$ had anti-MICA antibodies, in comparison with $46 \%$ and $7 \%$ patients with functioning grafts who had anti-HLA and antiMICA antibodies, respectively.

Zou Y. et al. determined the presence of antiMICA antibodies in kidney recipients before the transplantation [65]. They found that 217 out of 1910 patients (11.4\%) had anti-MICA antibodies with 1-year graft survival rate of $88.3 \pm 2.2 \%$ as compared to 93.0 $\pm 0.6 \%$ among patients in the MICA antibody-negative group $(p=0.01)$. According to Zou $Y$. et al. MICA antigens are significantly associated with and might play a role in rejection, in the absence of previous sensitization against HLA, like in recipients of first 
transplants, patients who received grafts from wellHLA-matched donors and recipients not previously sensitized against HLA. The role of anti-HLA and antiMICA antibodies in graft failure was confirmed in several studies [66-68].

Table 4: Studies of major histocompatibility complex class I chain-related gene $A$ antibodies in kidney transplant recipients.

\begin{tabular}{|c|c|c|c|c|c|c|}
\hline Authors & Year & $\begin{array}{l}\text { Time of } \\
\text { serum }\end{array}$ & Method & $\begin{array}{l}\text { Anti- } \\
\text { MICA }\end{array}$ & $\begin{array}{c}\text { Number } \\
\text { Or } \%\end{array}$ & $\mathbf{p}$ \\
\hline \multirow{2}{*}{$\begin{array}{l}\text { Mizutani } \\
\text { et al.[62] }\end{array}$} & \multirow{2}{*}{2005} & \multirow{2}{*}{ PostTx } & \multirow{2}{*}{ CDC } & + & 28 & \multirow{2}{*}{$<0.05$} \\
\hline & & & & - & 37 & \\
\hline \multirow{2}{*}{$\begin{array}{l}\text { Ozawa M. } \\
\text { et al.[64] }\end{array}$} & \multirow{2}{*}{2006} & \multirow{2}{*}{ PostTx } & \multirow{2}{*}{ Luminex } & + & $12 \%$ & \\
\hline & & & & - & $88 \%$ & \\
\hline \multirow{2}{*}{$\begin{array}{l}\text { Zou Y. et } \\
\text { al.[65] }\end{array}$} & \multirow{2}{*}{2007} & \multirow{2}{*}{ PreTx } & \multirow{2}{*}{ Luminex } & + & 217 & \multirow{2}{*}{$=0.01$} \\
\hline & & & & - & 1693 & \\
\hline \multirow{2}{*}{$\begin{array}{l}\text { Terasaki } \\
\text { et al.[66] }\end{array}$} & \multirow{2}{*}{2007} & \multirow{2}{*}{ PostTx } & \multirow{2}{*}{ Luminex } & + & 52 & \multirow{2}{*}{$<0.01$} \\
\hline & & & & - & 1872 & \\
\hline \multirow{2}{*}{$\begin{array}{l}\text { Zhang } \\
\text { Ming et } \\
\text { al. [67] }\end{array}$} & \multirow[b]{2}{*}{2011} & \multirow[b]{2}{*}{ PostTx } & \multirow[b]{2}{*}{ Luminex } & + & 15 & \\
\hline & & & & - & 37 & \\
\hline \multirow{2}{*}{$\begin{array}{l}\text { Zuowei Li } \\
\text { et al.[68] }\end{array}$} & \multirow{2}{*}{2012} & \multirow{2}{*}{ PostTx } & \multirow{2}{*}{ Luminex } & + & 11 & \multirow{2}{*}{$>0.05$} \\
\hline & & & & - & 57 & \\
\hline \multirow{2}{*}{$\begin{array}{l}\text { Anne } \\
\text { Lemi } \\
\text { al.[69] }\end{array}$} & \multirow[b]{2}{*}{2012} & \multirow[b]{2}{*}{ PostTx } & \multirow[b]{2}{*}{ Luminex } & + & 42 & \\
\hline & & & & - & 737 & \\
\hline
\end{tabular}

However, Lemy A. at al. in a study of 779 kidney transplant recipients in 2012 [69], obtained different results from the ones mentioned before. They found no statistical significance in the four-year deathcensored graft survival between $\mathrm{MICA}+$ and MICApatients ( $97 \%$ vs. $94 \%, P=0.28)$ and also the rates of acute rejection $(A R)$ and chronic antibody-mediated rejection (CAMR) were compatible between the two groups (AR: $6.3 \%$ vs. 3.8\%, $P=1.0$; CAMR: $18.8 \%$ vs. $15.4 \% ; P=1.0)$. By multivariate analysis, graft loss was associated with HLA DR mismatches, AR within the $1^{\text {st }}$ year, serum creatinin at 1 year $\geq 1.5 \mathrm{mg} / \mathrm{dL}$ and presence of HLA antibodies, but not MICA antibodies. Although they do not rule out the pathological effect of anti-MICA antibodies, there are certain methodological limitations (low prevalence, confounding by HLA antibodies) that are likely to prevail in any study looking at the role of MICA in graft failure.

Recently, consensus guidelines on the testing and clinical management issues associated with HLA and non-HLA antibodies in transplantation, was published [70] and comprehensive list of recommendations were provided covering the technical, pretransplantation and posttransplantation monitoring of HLA antibodies in solid organ transplantation. It was emphasized that the presence of preexisting antibodies to MICA has been shown to correlate with kidney graft outcome in some studies and not in others (Table 4). Although the data support the association of anti-MICA antibodies with allograft failure, the hypothesis that MICA antibodies are causal has not been proven.

Based on current evidence, the pretransplantation and posttransplantation group in the consensus recommendations, does not recommend routine pretransplantation testing for nonHLA antibodies [70]. In the section Future directions and research, it was mentioned that future studies are required to define the role of preexisting non-HLA antibodies on the outcome of solid organ and cellular transplantations.

\section{Anti-MICA antibodies in heart transplantation}

The role of anti-MICA antibodies, in absence of anti-HLA antibodies, in acute heart allograft rejection was investigated by Suarez-Alvarez et coworkers [71]. They examined 190 pre- and posttransplant serum samples from 44 patients collected during the first year after transplantation. Anti-MICA antibodies were significantly higher among the ones with severe acute rejection (AR) than those without rejection were $(60.7 \%$ vs. $14.3 \%, p=0.0038$ by complement-dependent cytotoxicity (CDC); $55.5 \%$ vs. $5.7 \%, p=0.0020$ by Luminex). They observed wider specificity of anti-MICA antibodies by Luminex than CDC assay and all patients developed anti-MICA antibodies against three or more alleles, which can suggest possible cross reactivity among alleles. All patients who had positive MICA Ab posttransplantation and developed $A R$ had donor-specific antibodies (DSA), which can suggest that the appearance of anti-MICA antibodies before the episodes of rejection can contribute to the development of the rejection. The level of expression of MICA in endomyocardial biopsies was examined with quantitative RT-PCR from 10 cardiac transplant recipients within the first year after transplantation and found that MICA mRNA expression levels were higher in biopsies with rejection (grade $3 \mathrm{~A} / 3 \mathrm{~B}$ or $2 \mathrm{R} / 3 \mathrm{R}$ ) than in biopsies without rejection (grade $<3 A$ or $2 \mathrm{R}$ ). There was absent MICA staining in heart biopsies not showing rejection. Thus, the monitoring of anti-MICA antibodies in heart transplantation may be useful marker for early detection of AR. Kauke T. and colleagues [72] in a group of 159 patients screened for anti-MICA $\mathrm{Ab}$ after the transplantation confirmed these findings. Thirty six $(22.6 \%)$ of them were positive for anti-MICA $A b$ and they found statistical significance between the presence of post-transplant specified anti-MICA $\mathrm{Ab}$ in patients sera and acute rejection and cardiac allograft vasculopathy.

However, a study done by J.D. Smith and colleagues [73] found no correlation between the presence of anti-MICA antibodies and graft survival following heart transplantation. Their study included pretransplant serum from 491 and posttransplant serum from 196 adult cardiac allograft recipients who were negative for anti-HLA antibodies. They found no effect of pretransplant or posttransplant production of MICA antibodies on the number of AR episodes in the first year, or cardiac allograft vasculopathy assessed the third and fifth year. Furthermore, the immunochemistry of cardiac biopsies from 11 patients did not demonstrate presence of MICA antigen. This data suggest that anti-MICA Ab alone have small 
effect on graft survival unlike anti-HLA antibodies whose effect on graft survival after heart transplantation and increased incidence of acute rejection is well documented [74].

\section{Association of mismatching for MICA with graft versus host disease after stem cell transplantation}

One of the major causes of mortality after allogeneic hematopoietic stem cell transplantation (HSCT) is graft-versus-host disease (GVHD). It was hypothesized by Parmar S. et al. [75] that MICA antigens can be recognized as transplantation antigens and may cause GVHD after HSCT in a cohort of 236 patients with myeloid leukemia. $73 \%$ of them had 10/10 matches in HLA-A, B, C, DR and DQ and only $8.4 \%$ were MICA mismatched. They observed higher rate of grade II-IV acute GVHD in the MICA mismatched patients ( $80 \%$ vs. $40 \%, P=0.003)$ and higher occurrence of gastrointestinal acute GVHD due to the expression of MICA antigens on the gastrointestinal epithelium and the fact that they can be induced on dendritic cells that play an essential role in antigen presentation processes that initiate GVHD [52]. The effect of anti-MICA Abs was investigated in the same year by another group of researchers who came to similar results [76]. They found that patients bearing MICA-129 val/val genotype were at higher risk of developing chronic GVHD (63\% vs. $45 \%$ at 3 years; $P=0.03)$ in a group of 211 patient and donor pairs typed for MICA-129 alleles. They also determined the level of soluble MICA in the sera of 116 patients and found highly significant association between posttransplantation sMICA higher than $80 \mathrm{pg} / \mathrm{mL}$ and the incidence of cGVHD. However, the presence of anti-MICA antibodies before transplantation correlated with low levels of SMICA after transplantation and thus low incidence of CGVHD, which strongly suggests neutralizing effect of MICA antibodies on SMICA.

\section{Conclusion}

The major histocompatibility complex class 1 chain-related gene $\mathrm{A}(\mathrm{MICA})$ polymorphisms are associated with different inflammatory diseases, infections diseases and tumors. Many studies confirm their role in the pathogenesis of these diseases. AntiMICA antibodies are important risk factors for antibody-mediated rejection after kidney and heart transplantation, thus their analysis is important in patients follow up after transplantation. GVHD after HSCT is more frequent in patients who were mismatched for MICA.

In spite of lack of conclusive data about the role of anti-MICA antibodies in organ and stem cell transplantation, there is still clinical relevance for investigation of the polymorphisms of the MICA gene and anti-MICA antibodies, especially meta-analysis of all published studies.

\section{Acknowledgements}

Ss Cyril and Methodius University of Skopje PhD School covered publication fee for this review article.

\section{References}

1. Bahram S, Bresnahan M, Geraghty DE, Spies T. A second lineage of mammalian major histocompatibility complex class I genes. Proceedings of the National Academy of Sciences of the United States of America . 1994;91(14):6259-63.

2. Leelayuwat C, Townend DC, Degli-Esposti MA, Abraham LJ, Dawkins RL. A new polymorphic and multicopy MHC gene family related to nonmammalian class I. Immunogenetics. 1994;40(5):339-51.

3. Shiina T, Inoko H, Kulski JK. An update of the HLA genomic region, locus information and disease associations: 2004. Tissue antigens. 2004;64(6):631-49.

4. Shiina T, Hosomichi K, Inoko H, Kulski JK. The HLA genomic loci map: expression, interaction, diversity and disease. Journal of human genetics. 2009;54(1):15-39.

5. MIC Genes [M.Tevfik DORAK]

6. Groh V, Bahram S, Bauer S, Herman a, Beauchamp M, Spies T. Cell stress-regulated human major histocompatibility complex class I gene expressed in gastrointestinal epithelium. Proceedings of the National Academy of Sciences of the United States of America. 1996;93(22):12445-50.

7. Bauer S. Activation of NK Cells and T Cells by NKG2D, a Receptor for Stress-Inducible MICA. Science. 1999;285(5428):727-9

8. Zwirner NW, Dole K, Stastny P. Differential surface expression of MICA by endothelial cells, fibroblasts, keratinocytes, and monocytes. Human Immunology. 1999;60(4):323-30.

9. Zwirner NW, Fernández-Viña MA, Stastny P. MICA, a new polymorphic HLA-related antigen, is expressed mainly by keratinocytes, endothelial cells, and monocytes. Immunogenetics. 1998;47(2):139-48.

10. Schrambach S, Ardizzone M, Leymarie V, Sibilia J, Bahram S. In vivo expression pattern of MICA and MICB and its relevance to auto-immunity and cancer. PloS one. 2007;2(6):e518.

11. Pende D, Cantoni $C$, Rivera $P$, Vitale $M$, Castriconi $R$, Marcenaro S, et al. Role of NKG2D in tumor cell lysis mediated by human NK cells: cooperation with natural cytotoxicity receptors and capability of recognizing tumors of nonepithelial origin. European journal of immunology. 2001;31(4):1076-86.

12. Zwirner N, Fuertes M. Immunobiology of the human MHC class I chain-related gene A (MICA): from transplantation immunology to tumor immune escape. Immunologia. 2006;25(1):25-38.

13. Tian W, Boggs $D$ a, Ding WZ, Chen DF, Fraser $P$ a. MICA genetic polymorphism and linkage disequilibrium with HLA-B in 29 African-American families. Immunogenetics. 2001;53(9):724-8.

14. Fodil N, Pellet P, Laloux L, Hauptmann G, Theodorou I, Bahram S. MICA haplotypic diversity. Immunogenetics. 1999;49(6):55760.

15. Rees MT, Downing J, Darke C. A typing system for the major histocompatibility complex class I chain related genes $A$ and $B$ using polymerase chain reaction with sequence-specific primers. Genetic testing. 2005;9(2):93-110. 
16. Mameli a, Cauli a, Taccari E, Scarpa R, Punzi L, Lapadula G, et al. Association of MICA alleles with psoriatic arthritis and its clinical forms. A multicenter Italian study. Clinical and experimental rheumatology. 2008;26(4):649-52.

17. Romphruk A V, Romphruk A, Choonhakarn C, Puapairoj C, Inoko $\mathrm{H}$, Leelayuwat $\mathrm{C}$. Major histocompatibility complex class chain-related gene $A$ in Thai psoriasis patients: MICA association as a part of human leukocyte antigen-B-Cw haplotypes. Tissue antigens. 2004;63(6):547-54.

18. Pollock R, Chandran V, Barrett J, Eder L, Pellett F, Yao C, et al. Differential major histocompatibility complex class I chainrelated $\mathrm{A}$ allele associations with skin and joint manifestations of psoriatic disease. Tissue antigens. 2011;77(6):554-61.

19. Groh V, Bruhl A, El-Gabalawy H, Nelson JL, Spies T. Stimulation of $\mathrm{T}$ cell autoreactivity by anomalous expression of NKG2D and its MIC ligands in rheumatoid arthritis. Proceedings of the National Academy of Sciences of the United States of America . 2003;100(16):9452-7.

20. Kirsten H, Petit-Teixeira E, Scholz M, Hasenclever D Hantmann $\mathrm{H}$, Heider $\mathrm{D}$, et al. Association of MICA with rheumatoid arthritis independent of known HLA-DRB1 risk alleles in a family-based and a case control study. Arthritis research \& therapy. 2009;11(3):R60.

21. Su H, Wang B, Zhang X, Hao J, Xiao Q, Ye D. [Disequilibrium linkage between the polymorphism in exons 2,3 and 4 of the MICA gene and HLA-B antigen of patient with ankylosing spondylitis]. Zhonghua yi xue yi chuan xue za zhi = Zhonghua yixue yichuanxue zazhi $=$ Chinese journal of medical genetics. 2006;23(4):446-8.

22. Yabuki K, Ota M, Goto K, Kimura T, Nomura E, Ohno S, et al Triplet repeat polymorphism in the MICA gene in HLA-B27 positive and negative caucasian patients with ankylosing spondylitis. Human immunology. 1999;60(1):83-6.

23. Goto K, Ota M, Maksymowych WP, Mizuki N, Yabuki K, Katsuyama $\mathrm{Y}$, et al. Association between MICA gene A4 allele and acute anterior uveitis in white patients with and without HLA-B27. American journal of ophthalmology. 1998;126(3):436-41.

24. Hughes EH, Collins RWM, Kondeatis E, Wallace GR, Graham EM, Vaughan RW, et al. Associations of major histocompatibility complex class I chain-related molecule polymorphisms with Behcet's disease in Caucasian patients. Tissue antigens. 2005; 66(3):195-9.

25. Muñoz-Saá I, Cambra A, Pallarés L, Espinosa G, Juan A Pujalte $F$, et al. Allelic diversity and affinity variants of MICA are imbalanced in Spanish patients with Behçet's disease. Scandinavian journal of immunology. 2006;64(1):77-82.

26. Gladman DD, Urowitz MB, Darlington GA. Disease expression and class II HLA antigens in systemic lupus erythematosus. Lupus. 1999;8(6):466-70.

27. Gambelunghe G, Gerli R, Bocci EB, Del Sindaco P, Ghaderi M, Sanjeevi CB, et al. Contribution of MHC class I chain-related A (MICA) gene polymorphism to genetic susceptibility for systemic lupus erythematosus. Rheumatology (Oxford, England). 2005;44(3):287-92.

28. Yoshida K, Komai K, Shiozawa K, Mashida A, Horiuchi T, Tanaka $\mathrm{Y}$, et al. Role of the MICA polymorphism in systemic lupus erythematosus. Arthritis and rheumatism. 2011;63(10):3058-66.

29. Hüe S, Mention J-J, Monteiro RC, Zhang S, Cellier C, Schmitz $\mathrm{J}$, et al. A direct role for NKG2D/MICA interaction in villous atrophy during celiac disease. Immunity. 2004;21(3):367-77.

30. Bilbao JR, Martín-Pagola A, Vitoria JC, Zubillaga P, Ortiz L, Castaño L. HLA-DRB1 and MHC class 1 chain-related A haplotypes in Basque families with celiac disease. Tissue antigens. 2002;60(1):71-6.

31. Rueda B, Pascual M, López-Nevot MA, Koeleman BPC, Ortega
E, Maldonado J, et al. Association of MICA-A5.1 allele with susceptibility to celiac disease in a family study. The American journal of gastroenterology. 2003;98(2):359-62.

32. Bilbao JR, Martín-Pagola A, Pérez De Nanclares G, Calvo B, Vitoria JC, Vázquez $F$, et al. HLA-DRB1 and MICA in autoimmunity: common associated alleles in autoimmune disorders. Annals of the New York Academy of Sciences. 2003;1005:314-8

33. Gambelunghe G, Ghaderi M, Tortoioli C, Falorni A, Santeusanio $F$, Brunetti $P$, et al. Two distinct MICA gene markers discriminate major autoimmune diabetes types. The Journal of clinical endocrinology and metabolism. 2001;86(8):3754-60.

34. Törn C, Gupta M, Nikitina Zake L, Sanjeevi CB, Landin-Olsson M. Heterozygosity for MICA5.0/MICA5.1 and HLA-DR3DQ2/DR4-DQ8 are independent genetic risk factors for latent autoimmune diabetes in adults. Human immunology. 2003;64(9):902-9.

35. Alizadeh BZ, Eerligh P, Van der Slik AR, Shastry A, Zhernakova $A$, Valdigem $G$, et al. MICA marks additional risk factors for Type 1 diabetes on extended HLA haplotypes: an association and meta-analysis. Molecular immunology. 2007;44(11):280612.

36. Van Autreve JE, Koeleman BPC, Quartier E, Aminkeng F, Weets I, Gorus FK, et al. MICA is associated with type 1 diabetes in the Belgian population, independent of HLA-DQ. Human immunology. 2006; 67(1-2):94-101.

37. Barker JM. Clinical review: Type 1 diabetes-associated autoimmunity: natural history, genetic associations, and screening. The Journal of clinical endocrinology and metabolism. 2006;91(4):1210-7.

38. Barahmani N, De Andrade M, Slusser JP, Zhang Q, Duvic M. Major histocompatibility complex class I chain-related gene A polymorphisms and extended haplotypes are associated with familial alopecia areata. The Journal of investigative dermatology. 2006;126(1):74-8.

39. Kumar V, Yi Lo PH, Sawai H, Kato N, Takahashi A, Deng Z, et al. Soluble MICA and a MICA variation as possible prognostic biomarkers for HBV-induced hepatocellular carcinoma. PloS one. 2012;7(9):e44743.

40. Li J-J, Pan K, Gu M-F, Chen M-S, Zhao J-J, Wang H, et al. Prognostic value of soluble MICA levels in the serum of patients with advanced hepatocellular carcinoma. Chinese journal of cancer. 2012;32(3):141-8.

41. Jiang $\mathrm{X}$, Zou $\mathrm{Y}$, Huo Z, Yu P. Association of major histocompatibility complex class I chain-related gene A microsatellite polymorphism and hepatocellular carcinoma in South China Han population. Tissue antigens. 2011;78(2):1437.

42. Luo QZ, Lin L, Gong Z, Mei B, Xu YJ, Huo Z, et al. Positive association of major histocompatibility complex class I chainrelated gene A polymorphism with leukemia susceptibility in the people of Han nationality of Southern China. Tissue antigens. 2011;78(3):178-84.

43. Fuertes MB, Rossi LE, Peralta CM, Cabrera HN, Allevato MA Zwirner NW. Premalignant quiescent melanocytic nevi do not express the MHC class I chain-related protein A. Medicina. 2011;71(4):357-60.

44. Das H, Groh V, Kuijl C, Sugita M, Morita CT, Spies T, et al. MICA engagement by human Vgamma2Vdelta2 $T$ cells enhances their antigen-dependent effector function. Immunity. 2001;15(1):83-93

45. Souza CF, Noguti EN, Visentainer JEL, Cardoso RF, Petzl-Erler $\mathrm{ML}$, Tsuneto LT. HLA and MICA genes in patients with tuberculosis in Brazil. Tissue antigens. 2012;79(1):58-63.

46. Do Sacramento WS, Mazini PS, Franceschi DAS, De Melo FC, Braga MA, Sell AM, et al. Frequencies of MICA alleles in patients from southern Brazil with multibacillary and 
paucibacillary leprosy. International journal of immunogenetics. 2012;39(3):210-5.

47. Tosh K, Ravikumar M, Bell JT, Meisner S, Hill AVS, Pitchappan R. Variation in MICA and MICB genes and enhanced susceptibility to paucibacillary leprosy in South India. Human molecular genetics. 2006;15(19):2880-7.

48. Groh V, Rhinehart R, Randolph-Habecker J, Topp MS, Riddel SR, Spies T. Costimulation of CD8alphabeta T cells by NKG2D via engagement by MIC induced on virus-infected cells. Nature immunology. 2001;2(3):255-60.

49. Zou Y, Bresnahan W, Taylor RT, Stastny P. Effect of human cytomegalovirus on expression of $\mathrm{MHC}$ class I-related chains $\mathrm{A}$. Journal of immunology. 2005;174(5):3098-104.

50. Moenkemeyer M, Heiken H, Schmidt RE, Witte T. Higher risk of cytomegalovirus reactivation in human immunodeficiency virus1 -infected patients homozygous for MICA5.1. Human immunology. 2009;70(3):175-8.

51. Kanto T, Hayashi N. Innate immunity in hepatitis C virus infection: Interplay among dendritic cells, natural killer cells and natural killer T cells. Hepatology research: the official journal of the Japan Society of Hepatology. 2007;37 Suppl 3:S319-26.

52. Jinushi M, Takehara T, Kanto T, Tatsumi T, Groh V, Spies T, et al. Critical role of $\mathrm{MHC}$ class I-related chain A and B expression on IFN-alpha-stimulated dendritic cells in NK cell activation: impairment in chronic hepatitis $\mathrm{C}$ virus infection. Journal of immunology (Baltimore, Md.: 1950). 2003;170(3):1249-56.

53. Karacki PS, Gao X, Thio CL, Thomas DL, Goedert JJ, Vlahov $D$, et al. MICA and recovery from hepatitis $C$ virus and hepatitis $B$ virus infections. Genes and immunity. 2004;5(4):261-6.

54. Zwirner NW, Marcos CY, Mirbaha F, Zou Y, Stastny P Identification of MICA as a new polymorphic alloantigen recognized by antibodies in sera of organ transplant recipients. Human immunology. 2000;61(9):917-24.

55. Zou Y, Stastny P. Antibodies against major histocompatibility complex class I-related chain A in transplant recipients. Chinese medical journal. 2011;124(5):764-70.

56. Zou Y, Qin Z, Silveus A, Fan Y, Stastny P. Polymorphisms of MICA recognized by human alloantibodies. Immunogenetics. 2009;61(2):91-100.

57. Duquesnoy RJ, Mostecki J, Hariharan J, Balazs I. Structurally based epitope analysis of major histocompatibility complex class I-related chain A (MICA) antibody specificity patterns. Human immunology. 2008;69(12):826-32.

58. Stegall MD, Dean PG, Gloor J. Mechanisms of alloantibody production in sensitized renal allograft recipients. American journal of transplantation: official journal of the American Society of Transplantation and the American Society of Transplant Surgeons. 2009;9(5):998-1005.

59. Dragun D, Philippe A, Catar R. Role of non-HLA antibodies in organ transplantation. Current opinion in organ transplantation. 2012;17(4):440-5.

60. Zou Y, Mirbaha F, Lazaro A, Zhang Y, Lavingia B, Stastny P MICA is a target for complement-dependent cytotoxicity with mouse monoclonal antibodies and human alloantibodies. Human immunology. 2002;63(1):30-9.

61. Alvarez-Márquez A, Aguilera I, Gentil M a, Caro JL, Bernal G Fernández Alonso $\mathrm{J}$, et al. Donor-specific antibodies against HLA, MICA, and GSTT1 in patients with allograft rejection and C4d deposition in renal biopsies. Transplantation. 2009;87(1):94-9.

62. Mizutani K, Terasaki P, Rosen A, Esquenazi V, Miller J, Shih RNJ, et al. Serial ten-year follow-up of HLA and MICA antibody production prior to kidney graft failure. American journal of transplantation: official journal of the American Society of Transplantation and the American Society of Transplant Surgeons. 2005;5(9):2265-72.
63. Martin L, Guignier F, Mousson C, Rageot D, Justrabo E, Rifle G. Detection of donor-specific anti-HLA antibodies with flow cytometry in eluates and sera from renal transplant recipients with chronic allograft nephropathy. Transplantation. 2003;76(2):395-400.

64. Ozawa M, Rebellato LM, Terasaki PI, Tong A, Briley KP, Catrou $P$, et al. Longitudinal testing of 266 renal allograft patients for HLA and MICA antibodies: Greenville experience. Clinical transplants. 2006;265-90.

65. Zou Y, Stastny P, Süsal C, Döhler B, Opelz G. Antibodies against MICA antigens and kidney-transplant rejection. The New England journal of medicine. 2007;357(13):1293-300.

66. Terasaki PI, Ozawa M, Castro R. Four-year follow-up of a prospective trial of HLA and MICA antibodies on kidney graft survival. American journal of transplantation: official journal of the American Society of Transplantation and the American Society of Transplant Surgeons. 2007;7(2):408-15.

67. Zhang M, Lu F, Qu L, He J, Yuan X, Gu Y. Serum majorhistocompatibility-complex class I-related chain $A$ antibody detection for the evaluation of graft dysfunction in renal allograft recipients. Chinese medical journal. 2011;124(14):2127-31.

68. Li Z, Luo M, Qiu J, Liu Y, Fan Y, Jahr FM, et al. Detection of antibodies against major histocompatibility complex class Irelated chain $A$ in long-term renal graft recipients. Experimental and clinical transplantation: official journal of the Middle East Society for Organ Transplantation. 2012;10(3):239-42.

69. Lemy A, Andrien M, Lionet A, Labalette M, Noel C, Hiesse C, et al. Posttransplant Major Histocompatibility Complex Class Chain-Related Gene A Antibodies and Long-Term Graft Outcomes in a Multicenter Cohort of 779 Kidney Transplant Recipients. Transplantation. 2012;93(12):1258-64.

70. Tait BD, Süsal C, Gebel HM, Nickerson PW, Zachary A a, Claas FHJ, et al. Consensus guidelines on the testing and clinical management issues associated with HLA and non-HLA antibodies in transplantation. Transplantation. 2013;95(1):19 47

71. Suárez-Alvarez $B$, López-Vázquez $A$, Gonzalez $M Z$, FdezMorera JL, Díaz-Molina B, Blanco-Gelaz MA, et al. The relationship of anti-MICA antibodies and MICA expression with heart allograft rejection. American journal of transplantation: official journal of the American Society of Transplantation and the American Society of Transplant Surgeons. 2007;7(7):18428.

72. Kauke T, Kaczmarek I, Dick A, Schmoeckel M, Deutsch M-A Beiras-Fernandez A, et al. Anti-MICA antibodies are related to adverse outcome in heart transplant recipients. The Journal of heart and lung transplantation: the official publication of the International Society for Heart Transplantation. 2009;28(4):30511.

73. Smith JD, Brunner VM, Jigjidsuren S, Hamour IM, McCormack a M, Banner NR, et al. Lack of effect of MICA antibodies on graft survival following heart transplantation. American journa of transplantation: official journal of the American Society of Transplantation and the American Society of Transplant Surgeons. 2009;9(8):1912-9.

74. Tambur AR, Bray RA, Takemoto SK, Mancini M, Costanzo MR Kobashigawa JA, et al. Flow cytometric detection of HLAspecific antibodies as a predictor of heart allograft rejection. Transplantation. 2000;70(7):1055-9.

75. Parmar S, Del Lima M, Zou Y, Patah P a, Liu P, Cano P, et al. Donor-recipient mismatches in MHC class I chain-related gene $A$ in unrelated donor transplantation lead to increased incidence of acute graft-versus-host disease. Blood. 2009;114(14):28847.

76. Boukouaci W, Busson $M$, Peffault de Latour R, Rocha V Suberbielle C, Bengoufa D, et al. MICA-129 genotype, soluble MICA, and anti-MICA antibodies as biomarkers of chronic graftversus-host disease. Blood. 2009;114(25):5216-24. 
77. Cheng L, Zhang SZ, Xiao CY, Hou YP, Li L, Luo HC, et al. The A5.1 allele of the major histocompatibility complex class I chainrelated gene $A$ is associated with psoriasis vulgaris in Chinese. The British journal of dermatology. 2000;143(2):324-9.

78. Gong W, Fan L, Yang J, Xu L, Yao F. [Analysis on polymorphism in exons 2,3 and 4 of the MICA gene in three different Chinese populations]. Zhonghua yi xue yi chuan xue za zhi $=$ Zhonghua yixue yichuanxue zazhi $=$ Chinese journal of medical genetics. 2002;19(4):336-9.

79. Nikitina-Zake, L; Gupta, M; Gambelunghe, G; Shtauvere, A; Lernmark ASCB. Frequencies of MICA alleles significantly differ between Latvian, Italian and Swedish populations and are associated with type 1 diabetes mellitius. Proceedings of the 13th IHW. 2006;2:379-80.

80. Ota M, Katsuyama $\mathrm{Y}$, Mizuki N, Ando $\mathrm{H}$, Furihata $\mathrm{K}$, Ono $\mathrm{S}$, et al. Trinucleotide repeat polymorphism within exon 5 of the MICA gene (MHC class I chain-related gene A): allele frequency data in the nine population groups Japanese, Northern Han, Hui, Uygur, Kazakhstan, Iranian, Saudi Arabian, Greek and Italian. Tissue antigens. 1997;49(5):448-54.

81. Piancatelli D, Del Beato T, Oumhani K, El Aouad R, Adorno D. MICA polymorphism in a population from north Morocco, Metalsa Berbers, using sequence-based typing. Human immunology. 2005;66(8):931-6.

82. Petersdorf EW, Shuler KB, Longton GM, Spies T, Hansen JA. Population study of allelic diversity in the human MHC class Irelated MIC-A gene. Immunogenetics. 1999;49(7-8):605-12.

83. Tian W, Boggs DA, Uko G, Essiet A, Inyama M, Banjoko B, et al. MICA, HLA-B haplotypic variation in five population groups of sub-Saharan African ancestry. Genes and immunity. 2003;4(7):500-5.

84. Oliveira LA, Ribas F, Bicalho MG, Tsuneto LT, Petzl-Erler ML. High frequencies of alleles $\mathrm{MICA}^{*} 020$ and $\mathrm{MICA}^{*} 027$ in Amerindians and evidence of positive selection on exon 3. Genes and immunity. 2008;9(8):697-705.

85. Zhang $Y$, Lazaro AM, Zou Y, Lavingia B, Moraes EM, Moraes $\mathrm{RJ}$, et al. MICA polymorphism in South American Indians. Immunogenetics. 2002;53(10-11):900-6.

86. Glas J, Martin K, Brünnler G, Kopp R, Folwaczny C, Weiss EH, et al. MICA, MICB and C1_4_1 polymorphism in Crohn's disease and ulcerative colitis. Tissue antigens. 2001;58(4):2439.

87. Romphruk A V, Naruse TK, Romphruk A, Kawata H, Puapairoj C, Kulski JK, et al. Diversity of MICA (PERB11.1) and HLA haplotypes in Northeastern Thais. Tissue antigens. 2001;58(2):83-9.

88. Zhang $Y$, Han M, Vorhaben R, Giang C, Lavingia B, Stastny P. Study of MICA alleles in 201 African Americans by multiplexed single nucleotide extension (MSNE) typing. Human immunology. 2003;64(1):130-6.

89. Cambra A, Muñoz-Saá I, Crespí C, Serra A, Etxagibel A, Matamoros $\mathrm{N}$, et al. MICA-HLA-B haplotype diversity and linkage disequilibrium in a population of Jewish descent from Majorca (the Balearic Islands). Human immunology. 2009;70(7):513-7.

90. Pyo C-W, Hur S-S, Kim Y-K, Choi H-B, Kim T-Y, Kim T-G. Distribution of MICA alleles and haplotypes associated with $\mathrm{HLA}$ in the Korean population. Human immunology. 2003;64(3):378-84.

91. Zhu F, Zhao H, He Y, Zhang W, He J, Xu X, et al. Distribution of MICA diversity in the Chinese Han population by polymerase chain reaction sequence-based typing for exons 2-6. Tissue antigens. 2009;73(4):358-63.

92. Sohn $Y-H$, Cha C-H, Oh H-B, Kim MH, Choi S-E, Kwon O-J. MICA polymorphisms and haplotypes with HLA-B and HLADRB1 in Koreans. Tissue antigens. 2010;75(1):48-55.

93. Zhang $\mathrm{Y}$, Lazaro AM, Lavingia B, Stastny $P$. Typing for all known MICA alleles by group-specific PCR and SSOP. Human immunology. 2001;62(6):620-31. 